\title{
Effect of Glucocorticoid on Adipose Tissue in Guinea Pigs
}

\author{
Susumu ADACHI \\ The Second Department of Internal Medicine, Osaka University, Medical School, \\ Osaka, Japan (Director : Professor Mitsuo Nishikawa, M.D.)
}

Differences in the metabolism between epididymal white fat and interscapular brown fat in guinea pigs were investigated in order to determine the effect of prednisolone on the release of free fatty acids (FFA) and the lipogenesis.

1) The release of FFA from adipose tissue in vitro into the incubation medium was increased $3 \mathrm{hrs}$, after the injection of $5 \mathrm{mg}$ of prednisolone both in brown fat and in white fat.

2) The addition of prednisolone into the incubation medium at the concentration of $0.8 \mu \mathrm{g} / \mathrm{ml}$ caused an increase in the release of FFA from interscapular brown fat, but not from epididymal white fat.

3) The addition of blood serum obtained from a guinea pig which had received an injection of prednisolone did increase the release of FFA in vitro from epididymal white fat obtained from the same animal, but did not increase the release of FFA from interscapular brown fat.

4) The release of FFA from interscapular brown fat in vitro was depressed in the animal which received an injection of $5 \mathrm{mg}$ of prednisolone per day for two weeks.

5) The long term administration of prednisolone resulted in an increase in the incorporation of glucose- $\mathrm{U}-{ }^{14} \mathrm{C}$ into the nonfatty acid portion of triglyceride in interscapular brown fat.

The fatty acid composition of this tissue showed an increase of palmitic acid and a decrease of linoleic acid after prednisolone treatment.

6) Results obtained in the present investigation show that the decrease in the release of FFA and the increase in lipogenesis in interscapular brown fat make favorable conditions for accumulation of fat in this tissue in giunea pigs treated with a long term administration of prednisolone.

(pp. 326 334) 


\title{
Glucocorticoid のモルモット脂肪組織に及ぼす影響
}

\author{
大阪大学符二内科学教室（主任 西川光夫教授）
}

足立進

（昭和43年12月16日受付）

\begin{abstract}
モルモットの epididymal fat と interscapular fat に及ばす prednisolone の影響について，脂肪 組織よりの FFA 放出と ${ }^{14} \mathrm{C}-$ glucose の脂肪組織への取り込みより比較した. prednisolone の一回投与. では interscapular fat からの FFA 放出が増加する. しかし, 長期間投与すると interscapular fat よりの FFA 放出は epididymal fat と異なり抑制され，また fatty acid より triglyceride の合成 が增加することは，ての組織䎲脂肪が蓄積するのに有利な条件を作つている。
\end{abstract}

\section{I 緒 言}

臨床的に glucocorticoid の長期投与の場合や Cushing 症候群に於 $て$, moon-face や buffalo hump 等 の語で表現される特異な脂肪沈着を伴う肥満が見られる，肥満そのものについては，精神作用による食事摂 取の増加，膵 $\beta$ 細胞の肥大又は過形成による insulin の分泌過㮃等が原因として考党られているが，局所 的な脂肪沈着については，局所の脂肪組謝のホルモンに対する感受性等の特異性を考虑しなければならない， 種々の動物に glucocorticoid を投与すると, interscapular の brown fat は white fat と異り，肥大 するてとが報告されている ${ }^{122)}$. 著者もモルモットに prednisolone を長期間投与した所， epididymal の white fat そは変化がないのに, interscapular の brown fat はかなり増加するのを認めた。 そてで本研 究においてての 2 つ脂肪組織に及ぼす prednisolone の影響を, 脂肪組織からのFFA 放出と, lipogenesis の面から比較榆討した.

\section{II 実 験 対 象}

実験動物としては，体重 300～350g の雄性純系モルモットを使用した。オリエンタル固形食 (繁殖用G) そて $1 \sim 2$ 週間飼育後, 実験前14時間は絶食にした.

\section{III 実 験 方 法}

\section{(1) 実験条件}

a) prednisolone $の$ in vivo 投与

i) prednisolone 1 回投与の影響の観察.

14時間絶食させた雄性モルモットに水溶性 prednisolone (prednisolone sodium hemisuccinate 塭野義 製薬製） $5 \mathrm{mg}$ を生理的食塩水 $0.25 \mathrm{ml}$ 亿溶解して, 大腿静脈より静注した。対照モルモットには生理的食 塩水 $0.25 \mathrm{ml}$ を同様に静注した。静注 3 時間後動物を実験と供し, epididymal fat と interscapular fat か らの in vitro での FFA 放出を測定した.

ii) prednisolone 長期投与の影響の観察

prednisolone $5 \mathrm{mg}$ を 2 週間每日筋注し, 最後の筋注後24時間で実験に供した。

epididymal fat と interscapular fat からの in vitro での FFA 放出, glucose-U $-{ }^{14} \mathrm{C}$ の上記脂肪組織 への取りこみ及び上記脂肪組織の脂酸構成を測定した。 
iii) prednisolone 長期投与後，追加投与の影響の観察.

ii）の如く prednisolone を投与した後, 最後の筋注から24時間で更に i) の如く prednisolone を追加 静注し， 3 時間後に実験に供した。 上記 2 種の脂肪組織からの in vitro での FFA 放出を測定した.

b) in vitro での prednisolone の添加並に prednisolone 注射をうけた動物の血清の添加.

i) medium 中に $0.08 \mu \mathrm{g} / \mathrm{ml}, 0.8 \mu \mathrm{g} / \mathrm{ml}$ の濃度に prednisolone を添加し, 脂肪組織からの FFA 放出に 対する影響を観察した。

ii) prednisolone $5 \mathrm{mg}$ を a - i) の如く静注して 3 時間後に反対側の大腿静脈より採血し，血清を分離し た。 この血清及び対照として prednisoloneの注射をうけていない動物の血清 $0.2 \mathrm{ml}$ を incubation medium に添加し, 脂肪組織からの FFA 放出に対する影響を観察した。

\section{(2) 測定方法}

a) 脂肪組織汃らの FFA 放出の測定

14時間絶食後モルモットを断頭屠殺し， epididymal fat 及び interscapular fat を採取した. 350〜400m の脂肪組織を incubation flask 中で $3 \%$ bovine albumin 加 Krebs-Ringer bicarbonate buffer $2.5 \mathrm{ml}$ を medium として $95 \% \mathrm{O}_{2}, 5 \% \mathrm{CO}_{2}$ 混合ガスの下で, $37^{\circ} \mathrm{C}, 60$ 分振蕰し, その間に medium 中に放出さ れる FFA を Dole ${ }^{3)} の$ 方法で測定した. 実験条件 b-ii) に対しては, albumin 加 buffer $2.3 \mathrm{ml}$ にモルモ ット血清 $0.2 \mathrm{ml}$ を加えたものを medium に用いた。

b) D-glucose-U $-{ }^{14} \mathrm{C}$ の脂肪組織の総脂質及び総脂酸への取りとみ及び $\mathrm{CO}_{2}$ への転化

$3 \%$ bovine albumin 加 Krebs-Ringer bicarbonate buffer $3.0 \mathrm{ml}$, glucose $40 \mu \mathrm{M}$, D-glucose- $\mathrm{U}_{-}{ }^{14} \mathrm{C} 1 \mu \mathrm{C}$ (第 1 化学薬品製) を含む medium 飞脂肪組織を入れ, $\mathrm{CO}_{2}$ を吸収するために副室に $1 \mathrm{M}$ hyamin $0.2 \mathrm{ml}$ を入れて，95\% $\mathrm{O}_{2}, 5 \% \mathrm{CO}_{2}$ 混合ガスを充填し， $37^{\circ} \mathrm{C} ， 180$ 分振蕰 incubation を行なつた. incubation 終 了後 $0.2 \mathrm{~N} \mathrm{H}_{2} \mathrm{SO}_{4} 1 \mathrm{ml}$ を medium 亿注入し, 更に 5 分間振温後, 副室の hyamin をトルエン $2 \mathrm{ml}$ で洗 い流してトルエン試薬 $8 \mathrm{ml}$ (toluene $500 \mathrm{ml}$ ，DPO 2g，POPOP 40mg） に入れ $\mathrm{CO}_{2}$ の放射能を liquid scintillation counter (Packard TRI-GARB Model 314EX) にて測定した. 次に脂肪組織を取り出して 生理的食塩水で 3 回洗涤後, クロロホルム: メタノール（2:1）混合液 $30 \mathrm{ml}$ で脂質を抽出, Folch の方 法 ${ }^{4)}$ で洗涤を行つた。試料を窒素気流下に減圧乾燥後, クロロホルム $3 \mathrm{ml}$ で脂質を再抽出し, この中 $1 \mathrm{ml}$ をトルエン試薬 $8 \mathrm{ml}$ に入れ総脂質の放射能を測定した。 又他の $1 \mathrm{ml}$ を取り, てれを減圧乾燥後, 飽和 $\mathrm{KOH}:$ エタノール (1:20) 混合液 $4 \mathrm{ml}$ 加光, 2 時間室温に放置して水解を行つた. 次に濃塩酸にて中 和後, 水 $2 \mathrm{ml}$, ヘプタン $3 \mathrm{ml}$ を加えて振晹した後, 上層より $2 \mathrm{ml}$ を採取してトルエン試薬 $8 \mathrm{ml}$ に入, 同様に放射能を測定した。

G) 脂肪組織の脂酸構成の測定

モルモットを断頭屠殺後, epididymal fat 及び interscapular fat の少量を取り, クロロホルム：メタ ノール（2:1）混合液 $30 \mathrm{ml}$ で脂質を抽出後, Folch の方法で洗滌し, Stoffel の方法 ${ }^{5)}$ 飞準じて塩酸、タ ノール溶液 $5 \mathrm{ml}$ で脂質を $80^{\circ} \mathrm{C}, 2$ 時間メチル化後, ガスクロマト分析に供した。ガスクロマトグラフィー は F \& M 社製 Model 400 を使用し，充填剤として diethylene glycol succinate polyester th chromosorb W に 15\% coating したものを用い, 窒素ガスを carrier gas として水素炎イオン化ディテクターを用い, カラム温度 $200^{\circ} \mathrm{C}$ に測定した。 各脂肪酸量は, ピーク面積を三角法にて計算し, 百分率で示した。

\section{IV 実 験 成 績}

\section{(1) prednisolone の脂肪組織からの FFA 放出に及ぼす影響}

\section{a) in vivo 投与}

i ) prednisolone 一回投与後 3 時間での脂肪組織からの FFA 放出

prednisolone 投与をうけた動物の脂肪組織は, epididymal fat, interscapular fat 共に, prednisolone 投与を受けない対照動物の脂肪組織に比べて FFA 放出の増加の傾向を示した (Table 1). その増加率は 
2 つの脂肪組織の間に差異を認めなかつた。

ii) prednisolone 長期投与の影響

prednisolone を2 週間にわたつて与兄られた動物の epididymal fat からの FFA 放出は対照動物のそ れと全く差がなかつた。乙れに対し，interscapular fat では，prednisolone 投与をうけた動物において， FFA 放出が著しく低下していた。 $(\mathrm{P}<0.01)$. (Table 2)

iii) prednisolone 長期投与後の追加投与の影響

prednisolone 投与を 2 週間にわたつてうけた動物に最終筋注投与後 24 時間で prednisolone $5 \mathrm{mg}$ を i) と同様静注で与え，追加投与をうけない群と比較した（Table 3). prednisolone の追加投与によつて epididymal fat, interscapular fat ともに脂肪組織からの FFA 放出は增加した。 しかしての場合でも

Table 1. Effect of single injection of prednisolone on FFA release from adipose tissue

\begin{tabular}{c|l|c|c}
\hline & & No. of exp. & FFA ( $\mu \mathrm{Eq} / \mathrm{gm} / 60 \mathrm{~min})$ \\
\hline $\begin{array}{c}\text { Epididymal } \\
\text { fat }\end{array}$ & Control & 4 & $2.48 \pm 0.17$ \\
& Prednisolone & 4 & $2.95 \pm 0.15$ \\
\hline $\begin{array}{c}\text { Interscapular } \\
\text { fat }\end{array}$ & Control & 4 & $1.46 \pm 0.07$ \\
& Prednisolone & 4 & $1.74 \pm 0.10$ \\
\hline
\end{tabular}

Prednisolone $5 \mathrm{mg}$ was injected intravenously.

$($ Mean \pm S.E. $)$

Table 2. Effect of long term administration of prednisolone on FFA release from adipose tissue

\begin{tabular}{c|l|c|l}
\hline & & No. of exp. & FFA $(\mu \mathrm{Eq} / \mathrm{gm} / 60 \mathrm{~min})$ \\
\hline $\begin{array}{c}\text { Epididymal } \\
\text { fat }\end{array}$ & Control & 5 & $2.13 \pm 0.13$ \\
& Prednisolone & 4 & $1.97 \pm 0.15$ \\
\hline $\begin{array}{c}\text { Interscapular } \\
\text { fat }\end{array}$ & Control & 7 & $2.58 \pm 0.13$ \\
& Prednisolone & 5 & $1.77 \pm 0.13 * \mathrm{P}<0.01$ \\
\hline
\end{tabular}

$($ Mean \pm S.E. $)$

Prednisolone 5mg per day was injectd intramuscularly for two weeks.

Table 3. Effect of additional injection of prednisolone on FFA release from adipose tissue in prednisolone treated guinea pig

\begin{tabular}{c|c|c|c}
\hline & $\begin{array}{l}\text { Additional injection } \\
\text { of prednisolone }\end{array}$ & No. of exp. & $\begin{array}{l}\text { Release of FFA } \\
\text { per cent of the control }\end{array}$ \\
\hline $\begin{array}{c}\text { Epididymal } \\
\text { fat }\end{array}$ & $(-)$ & 4 & $93 \pm 8$ \\
& $(+)$ & 5 & $122 \pm 9$ \\
\hline $\begin{array}{c}\text { Interscapular } \\
\text { fat }\end{array}$ & $(-)$ & 5 & $69 \pm 5$ \\
& $(+)$ & 5 & $98 \pm 5 * \mathrm{P}<0.025$ \\
\hline
\end{tabular}

$($ Mean \pm S.E. $)$

Prednisolone $5 \mathrm{mg}$ was injected intravenously to the guinea pigs which had been administered prednisolone $5 \mathrm{mg}$ per day intramuscularly for two weeks. 
interscapular fat では，2週間生理的食塩水を筋注した対照動物の脂肪組織よりの FFA 放出の程度を越 えなかつた。

(小括) prednisolone in vivo 投与の FFA 放出に及ぼす影響についてのまとめ.

white fat である epididymal fat と brown fat である interscapular fat の間には in vitro での脂 肪組織からの FFA 放出に関して, prednisolone 一回投与後短時間での影響に何らの差異を認めない. し かし長期間にわたつて投与した場合には, epididymal fat からの FFA 放出は対照と変りがないのに対し， interscapular fat からの FFA 放出は明らかに低下している。即ち interscapular fat では prednisolone 投与後一過性に FFA 放出が増加することはあつても, 全体としては対照よりも FFA 放出が少く, 脂肪の 蓄積に有利な条件を作つていると言える。

\section{b) in vitro の添加実験}

i ) prednisolone の添加

a-i）の変化が prednisolone の直接作用かどうかをみるため, medium に prednisolone を添加して in vitro での作用をみた。 epididymal fat からの FFA 放出は prednisolone 濃度 $0.08 \mu \mathrm{g} / \mathrm{ml}, 0.8 \mu \mathrm{g} / \mathrm{ml}$ 共 に in vitro での影響をうけなかつた。これに対して interscapular fat では $0.08 \mu \mathrm{g} / \mathrm{ml}$ で対照と差はなく, $0.8 \mu \mathrm{g} / \mathrm{ml}$ では有意の増加（ $\mathrm{P}<0.05 ）$ を示した（Table 4$)$.

ii) prednisolone 投与をうけた動物の血清の添加

prednisolone によつておてされる二次的因子の影響をみるため medium 中に prednisolone 注射 3 時間 後の血清を渿加して, 脂肪組織からの FFA 放出に対する作用を in vitro で観察した. prednisolone 投与 動物の血清は prednisolone 投与を行つていない対照動物の epididymal fat 及び interscapular fat から の FFA 放出を共に増加させたが，後者においては増加率が著しかつた（p＜0.005）(Table 5).

Table 4. Effect of prednisolone added in vitro on FFA release from adipose tissue

\begin{tabular}{c|c|c|c}
\hline & $\begin{array}{c}\text { Prednisolone } \\
(\mu \mathrm{g} / \mathrm{ml})\end{array}$ & No. of exp. & $\begin{array}{l}\text { Release of FFA } \\
\text { per cent of the control }\end{array}$ \\
\hline $\begin{array}{c}\text { Epididymal } \\
\text { fat }\end{array}$ & 0.08 & 5 & $107 \pm 11$ \\
& 0.8 & 5 & $109 \pm 10$ \\
\hline $\begin{array}{c}\text { Interscapular } \\
\text { fat }\end{array}$ & 0.08 & 6 & $113 \pm 9$ \\
& 0.8 & 5 & $177 \pm 25 * \mathrm{P}<0.05$ \\
\hline
\end{tabular}

$($ Mean \pm S.E. $)$

Table 5. Effect of serum added in vitro on FFA release from adipose tissue in control guinea pig

\begin{tabular}{|c|c|c|c|}
\hline & Addition in medium & No. of exp. & FFA $(\mu \mathrm{Eq} / \mathrm{gm} / 60 \mathrm{~min})$ \\
\hline \multirow{2}{*}{$\begin{array}{l}\text { Epididymal } \\
\text { fat }\end{array}$} & $\begin{array}{l}\text { Serum from control } \\
\text { animal }\end{array}$ & 4 & \\
\hline & $\begin{array}{l}\text { Serum from prednisolone } \\
\text { treated animal }\end{array}$ & 4 & $3.19 \pm 0.20 * \mathrm{P}<0.05$ \\
\hline \multirow{2}{*}{$\begin{array}{l}\text { Interscapular } \\
\text { fat }\end{array}$} & $\begin{array}{l}\text { Serum from control } \\
\text { animal }\end{array}$ & 4 & \\
\hline & $\begin{array}{l}\text { Serum from prednisolone } \\
\text { treated animal }\end{array}$ & 4 & $2.45 \pm 0.10 * \mathrm{P}<0.005$ \\
\hline
\end{tabular}

$($ Mean \pm S.E.) 
Table 6. Effect of serum added in vitro on FFA release from adipose tissue in prednisolone treated guinea pig

\begin{tabular}{|c|c|c|c|}
\hline & Addition in medium & No. of exp. & FFA $(\mu \mathrm{Eq} / \mathrm{gm} / 60 \mathrm{~min})$ \\
\hline \multirow{2}{*}{$\begin{array}{l}\text { Epididymal } \\
\text { fat }\end{array}$} & $\begin{array}{l}\text { Serum from control } \\
\text { animal }\end{array}$ & 4 & $2.95 \pm 0.15$ \\
\hline & $\begin{array}{l}\text { Serum from prednisolone } \\
\text { treated animal }\end{array}$ & 4 & $3.79 \pm 0.13 * \mathrm{P}<0.01$ \\
\hline \multirow{2}{*}{$\begin{array}{c}\text { Interscapular } \\
\text { fat }\end{array}$} & $\begin{array}{l}\text { Serum from control } \\
\text { animal }\end{array}$ & 4 & $1.74 \pm 0.10$ \\
\hline & $\begin{array}{l}\text { Serum from prednisolone } \\
\text { treated animal }\end{array}$ & 4 & $1.76 \pm 0.12$ \\
\hline
\end{tabular}

$($ Mean \pm S.E. $)$

また prednisolone を前以つて投与された動物の epididymal fat を用いた場合にも，その動物の血清 の添加によつて FFA 放出は更に増加した（P<0.01）。しかし同じ動物の interscapular fat では, その 動物の血清の添加による FFA 放出の増加は認められなかつた (Table 6).

（小括） in vitro 投与実験のまとめ

a) の in vivo での prednisolone の作用は少くとも epididymal fat そついては直接作用ではなく, prednisolone 注射によつて影響をうける他の因子によることが明らかになつた。 interscapular fat につい ては, prednisolone の高濃度での直接作用と共に，他の因子の働きの両者が存在すると考えられる。しか $し$ prednisolone 静注 3 時間後の interscapular fat では，同じ動物の，即ち prednisolone 投与 3 時間後 の血清の添加による FFA 放出の増加が見られないととから， prednisolone 投与によつて FFA 放出抑制 因子が動員され，乙の因子が interscapular fat の反応性を変化させたのではないかと考えられる。

\section{(2) glucose-U- ${ }^{14} \mathbf{C}$ の脂肪組織の総脂質, 総脂酸への取り込み及び $\mathrm{CO}_{2}$ への転化}

Table 7, 8 の様に, prednisolone を 2 週間投与したモルモットで glucose-U- ${ }^{14} \mathrm{C}$ の脂肪組織の総脂質へ の取りこみを対照と比較すると, prednisolone 投与群では, epididymal fat $(\mathrm{p}<0.05)$ 及び interscapular fat $(\mathrm{p}<0.01)$ で共に取りてみが増加していた。一方総脂酸への取りとみは両者共に対照と差がなかつた。

$\mathrm{CO}_{2}$ への転化は epididymal fat では増加の傾向を示したが interscapular fat では対照と差がなかつ た.

Table 7. Effect of long term administration of prednisolone on metabolism of glucose-U- ${ }^{14} \mathrm{C}$ by epididymal adipose tissue

\begin{tabular}{l|l|c|c}
\hline \hline & & No. of exp. & cpm/100mg w.w. \\
\hline \begin{tabular}{l|l|l} 
Incorporation of glucose \\
carbon into total lipid
\end{tabular} & $\begin{array}{l}\text { Control } \\
\text { Prednisolone }\end{array}$ & 4 & $1470 \pm 249$ \\
& 4 & $2730 \pm 349 * \mathrm{P}<0.05$ \\
\hline $\begin{array}{l}\text { Incorporation of glucose } \\
\text { carbon into total fatty acid }\end{array}$ & Control & 5 & $212 \pm 38$ \\
& Prednisolone & 4 & $228 \pm 34$ \\
\hline $\begin{array}{l}\text { Oxidation of glucose } \\
\text { carbon to CO }\end{array}$ & Control & 4 & $6520 \pm 1097$ \\
& Prednisolone & 4 & $9180 \pm 1033$ \\
\hline
\end{tabular}

$(\mathrm{Mean} \pm$ S.E. $)$

Prednisolone $5 \mathrm{mg}$ per day was injected intramuscularly for two weeks. 
Table 8. Effect of long term administration of prednisolone on metabolism of glucose- $\mathrm{U}-{ }^{14} \mathrm{C}$ by interscapular adipose tissue

\begin{tabular}{l|l|c|c}
\hline & & No. of exp. & cpm/100mg w.w. \\
\hline \begin{tabular}{l|c|c} 
Incorporation of glucose \\
carbon into total lipid
\end{tabular} & Control & 8 & $732 \pm 71$ \\
& Prednisolone & 6 & $1488 \pm 286 * \mathrm{P}<0.01$ \\
\hline $\begin{array}{l}\text { Incorporation of glucose } \\
\text { carbon into total fatty acid }\end{array}$ & Control & 5 & $195 \pm 19$ \\
& Prednisolone & 4 & $194 \pm 23$ \\
\hline $\begin{array}{l}\text { Oxidation of glucose } \\
\text { carbon to } \mathrm{CO}_{2}\end{array}$ & Control & 8 & $6980 \pm 408$ \\
\hline
\end{tabular}

$(\mathrm{Mean} \pm$ S.E. $)$

Prednisolone $5 \mathrm{mg}$ per day was injected intramuscularly for two weeks.

\section{(3) 脂肪組織の脂酸構成}

モルモットに2 週間 prednisolone を投与し， epididymal fat 及び interscapular fat の脂酸構成を対 照と比較すると, epididymal fat では Fig. 1 の様に対照群との間に差を認めなかつたが, interscapular fat では Fig. 2 の様に主として内因性に合成されるパルミチン酸の増加傾向及び必須脂酸であるリノール酸 の減少 $(\mathrm{P}<0.01)$ がみられた。

Fig. 1. Fatty acid composition of epididymal adipose tissue.

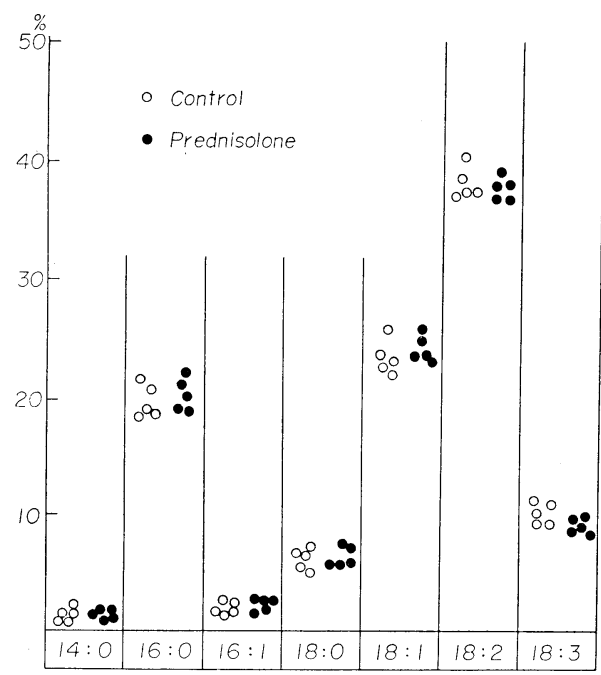

Prednisolone $5 \mathrm{mg}$ per day was injected intramuscularly for two weeks.

$16: 1$ palmitoleic acid

$16: 0$ palmitic acid

$18: 1$ oleic acid

18: 0 stearic acid

$18: 3$ linolenic acid
Fig. 2. Fatty acid composition of interscapular adipose tissue.

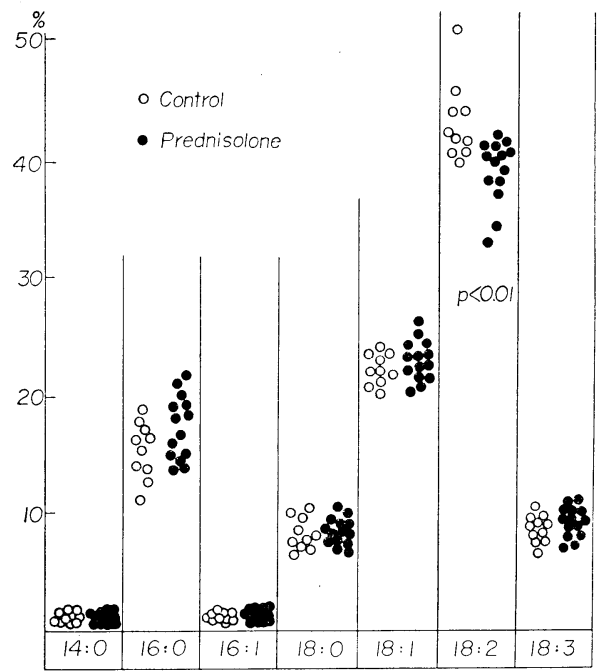

Prednisolone $5 \mathrm{mg}$ per day was injected intramuscularly for two weeks.

14:0 myristic acid $16: 0$ palmitic acid $16: 1$ palmitoleic acid $18: 0$ stearic acid $18: 1$ oleic acid $18: 2$ linoleic acid $18: 3$ linolenic acid 


\section{$\mathrm{V}$ 考案}

脂肪の沈着を来す原因として, 先づ貯蔵脂肪からの FFA 放出の変化があげられる.

prednisolone の長期投与がモルモットの interscapular fat からの FFA 放出を低下せしめ, glucose ${ }^{-14} \mathrm{C}$ の中性脂肪の非脂酸部分への incorporation を増加せしめることは脂肪蓄積に有利な条件を与えるもので あり，てれによつて prednisolone 投与による interscapular fat の増量を矛盾なく説明するととが出来る. glucocorticoid の脂肪組織に対する作用には，直接作用と他の hormonal level の変化を介しての間接作 用がある。本実験に於て，glucocorticoid (prednisolone) がかなりの高濃度においては，モルモットの

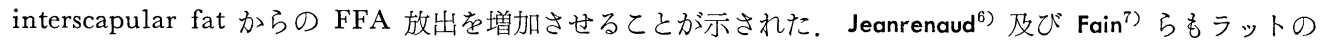
epididymal fat そ対し glucocorticoid が in vitro で直接作用を示すととを報告しているが，その作用は ACTH に比べて非常に弱いとされている，Fain ${ }^{8)}$ にれね゙ dexamethasone は in vitroでラットの white fat そ対し FFA 放出の増加をおてさせるが，brown fat には影響を与えない，てれは今回の実験における モルモットの両種脂肪組織に対する prednisolone の効果と全く逆であるが，恐らく動物の差によるもの であろう. Shafrir \& Kerpel ${ }^{9)}$ はラットの脂肪組織からの FFA 動員に及ぼす glucocorticoid の作用は epinephrine の fat mobilizing effect の助長によると報告した.

Kovacev 等 ${ }^{10111)}$ は in vitro で growth hormone 及び dexamethasone を単独添加した時には脂肪組織 からの FFA 動員は殆んど起らないが，両者を同時に添加すると著明な FFA 動員が起ると報告している. 今回の実験で prednisolone 自体が epididymal fat に対し FFA 放出の増加をおてさなかつたのに, prednisolone 投与動物の血清が FFA 放出を增加させたととは prednisolone 投与をうけた動物の 3 時間 後の血清中に FFA 放出を穴進させる hormonal factor が存在するてとを示している. また prednisolone 投与動物の血清が FFA 動員について epididymal fat よりも interscapular fat そ対しより大きな効果を 示すてとから, interscapular fat そ対しては prednisolone と二次的な hormonal facter の両者の作用が 重つていると考えられる。

一方 glucocorticoid は insulin 分泌を刺激するので(2)13)14) このために FFA 放出が抑制されるととも考 慮されなければならない. predisolone 投与を受けた動物の interscapular fat が同じ prednisolone 処理 動物の血清に対して感受性がないことは，ての組織が prednisolone 投与によつて一過性に増加した insulin または類似の hormonal factor の影響下にある可能性を示唆するものである.

prednisolone 長期投与による interscapular fat からの FFA 放出の低下については, insulin 分泌の増 加，副腎䯣質の萎縮，脳下垂体ホルモンの分泌低下が原因として考光られる。

Campbel $^{14)}$ はハムスターに cortisone を投与して血清インスリン濃度の変化を測定し, cortisone 投与 3 日後から著しく増量して投与前の 40 倍位に達すると報告している.

モルモットの脂肪組織は epinephrine に insensitive であるので ${ }^{15)}$, glucocorticoid 投与中の副腎髄質 の脂肪組織への関与については今の所資料がないが，大きな影響は考光難いととになる.

insulin は white fat と brown fat に対してほぼ同様に FFA 放出を抑制すると報告されている17)。し たがつて今回の実験でみられた prednisolone 長期投与の interscapular fat への影響を insulin の過剩 分泌だけに結びつけるのは困難で，他の因子の存在による可能性をも考光ねばならない， prednisolone 長 期投与によつて epididymal fat, interscapular fat 共に glucose-U- ${ }^{14} \mathrm{C}$ から総脂質への取りてみは増加す る。しかしいづれの脂肪組織でも脂酸部分への取りてみには対照と差がないので，ての結果は fatty acid から triglyceride の合成の增加を示すものと考光られる。

glucocorticoid の直接作用としては, white fat で glucose- ${ }^{14} \mathrm{C}$ の総脂質への取りてみの減少がおこる ${ }^{11)}$ 19)20221). Fain ${ }^{8)}$ によれば, ラットの white fat では dexamethasone の in vitro 添加により glucose- ${ }^{14} \mathrm{C}$ の総脂質への取りてみが抑制されるが， brown fat ではこの抑制がみられないという。長期投与の場合の 変化は恐らく insulin またはとれに類似の作用を持つ二次的因子によるものであうう. 
Steiner 等 ${ }^{16) 17) 18)}$ とると insulin は white fat, brown fat 共に glucose- ${ }^{14} \mathrm{C}$ の総脂質への取り込み及 び $\mathrm{CO}_{2}$ への転化を増加させる。 今回の実験では $\mathrm{CO}_{2}$ への転化に両脂肪組織の間に差異がみられたが，乙 れは interscapular fat における脂肪量の増加と細胞質の相対的減少によるのではないかと思われる.

interscapular fat そみられた脂肪組織の変化, 即ちパルミチン酸の増加傾向とリノール酸の減少は, 一 般的に脂肪合成の増加の結果であつて，特異的な脂肪沈着の原因に直接の関連はないと考えられる.

\section{$\mathrm{VI}$ 総 括}

glucocorticoid 投与によつて起る異常脂肪沈着の発作機作を知るために, モルモットの epididymal white fat と interscapular brown fat そ及ぼす prednisolone の影響を in vitro での脂肪組織からの FFA 放 出と lipogenesis の面から比較検討した. 更にてれ等の脂肪組織の脂酸構成についても分析を加えて次の結 果を得た。

1) prednisolone $5 \mathrm{mg}$ 一回静注の影響は, epididymal fat と interscapular fat とで差買はない. しか し，2 週間連続筋注した場合，epididymal fat では対照と差がないのに対し， interscapular fat では in vitro での脂肪組織からの FFA 放出が低下する.

2) prednisolone $0.8 \mu \mathrm{g} / \mathrm{ml}$ を in vitroに加えた場合, interscapular fat はこれに sensitiveであり FFA 放出が充進するが， epididymal fat は insensitive である. 対照脂肪組織に prednisolone 処理血清を加 えた場合に FFA 放出の増加がみられるが，てれは少くとも epididymal fat については prednisolone の 直接作用ではなく，血中に存在する他の因子によると思われる.

interscapular fat そついては prednisolone の高濃度での直接作用と共に，他の因子の働きが関与して いると考えられる.

prednisolone 静注 3 時間後の interscapular fat では, 同しく prednisolone 静注 3 時間後の血清の添 加は, FFA 放出を増加させない. このととは, この組織が prednisolone 投与によつて一過性に増加した insulin 又は類似の hormonal factor の影響下にある可能性を示唆する.

3) prednisolone を2 週間筋注し, glucose-U- ${ }^{14} \mathrm{C}$ のてれ等の脂肪組織への取りてみをみると, interscapular fat では総脂質への取り込みは epididymal fat と同様に増加するが， $\mathrm{CO}_{2}$ への転化は epididymal fat と異なり増加しない.

4) prednisolone 投与後の interscapular fat そおけるパルミチン酸の増加傾向, リノール酸の娍少は, 脂肪の蓄積している動的状態を示すものであるが, epididymal fat ではそのような変化はない.

5) prednisolone の長期投与がモルモットの interscapular fat からの FFA 放出を低下せしめ glucose から中性脂肪の非脂酸部分への転化を増加せしめることは, 脂肪蓄積に有利な条件を与えるものである.

擱筆に臨み，御䈍篤な御指導と御校閲を賜わつた恩師西川光夫教授，並びに終始御指導と御鞭撻を賜わつ た山本章講師に衣心より謝意を表します。又種々御教示と御援助を頂いた礒崎正弘博士, 大阪府立成人病セ ンター佐野元哉博士及び研究室の方々に厚く感謝いたします.

本論文の要旨は第40回日本内分泌学会総会, 第15回日本内分泌学会西部部会に招いて発表した.

\section{文献}

1) ARONSON, S.M., G.V. TEODORU, M. AdLER and G. SHWARTZMAN : Proc. Soc. Exp. Biol. Med., $85: 214$, (1954). $\quad$ 2) MAZZUCGHELLI, M.V., G. CONFALONIERI and P. SCHLECHTER : Metabolism, $10: 330$, (1960). $\quad 3)$ DOLE, V.P. : J. Clin. Invest., $35: 150$, (1956). $\quad 4$ ) FOLCH, J., M. LEES and G.H. SLOAN STANLEY : J. Biol. Ghem., 226 : 497, (1957). 5) StOFFEL, W., F. CHU and E.H. AHRENS, JR. : Anal. Chem., 31 : 307, (1959).

6) JEANRENAUD, B. and A.E. RENOLD : J. Biol. Chem., $235: 2217$, 
(1960).

7) FAIN, J.N., R.O. SCOW and S.S. CHERNICK : J. Biol. Ghem., 238 : 54, (1963).

14) CAMPBELL, J., K.S. RASTOGI and H.R. HAUSLER : Endocrinology, 79 : 749 , (1966).

15) RUDMAN, D., S.J. BROWN and M.F. MALKIN : Endocrinology, $72: 527$, (1963). STEINER, G. and G.F. GAHILL, J.R. : Am. J. Physiol., $211: 1325$, (1966).

17) FAIN, J.N., N. REED and R. SAPERSTEIN : J. Biol. Chem., 242 : 1887, (1967). 